\title{
In vitro studies reveal antiurolithic effect of Terminalia arjuna using quantitative morphological information from computerized microscopy
}

\author{
A. Mittal ${ }^{1}$, S. Tandon ${ }^{2}$, S.K. Singla ${ }^{3}$, C. Tandon ${ }^{4}$ \\ 1 Department of Biotechnology and Bioinformatics, Jaypee University of Information Technology, \\ Waknaghat, Solan 173234, Himachal Pradesh, India; ${ }^{2}$ Amity Institute of Molecular Medicine and Stem \\ Cell Research (AIMMSCR), Amity University Uttar Pradesh,Noida; ${ }^{3}$ Department of Biochemistry, Panjab \\ University, Chandigarh - 160014, India and ${ }^{4}$ Amity Institute of Biotechnology, Amity University Uttar \\ Pradesh, Sector - 125, Noida, U.P., 201313 India
}

\section{ABSTRACT}

Purpose: For most cases, urolithiasis is a condition where excessive oxalate is present in the urine. Many reports have documented free radical generation followed by hyperoxaluria as a consequence of which calcium oxalate ( $\mathrm{CaOx}$ ) deposition occurs in the kidney tissue. The present study is aimed to exam the antilithiatic potency of the aqueous extract (AE) of Terminalia arjuna (T. arjuna).

Materials and Methods: The antilithiatic activity of Terminalia arjuna was investigated in vitro nucleation, aggregation and growth of the $\mathrm{CaOx}$ crystals as well as the morphology of $\mathrm{CaOx}$ crystals using the inbuilt software 'Image-Pro Plus 7.0' of Olympus upright microscope (BX53). Antioxidant activity of AE of Terminalia arjuna bark was also determined in vitro.

Results: Terminalia arjuna extract exhibited a concentration dependent inhibition of nucleation and aggregation of $\mathrm{CaOx}$ crystals. The $\mathrm{AE}$ of Terminalia arjuna bark also inhibited the growth of $\mathrm{CaOx}$ crystals. At the same time, the $\mathrm{AE}$ also modified the morphology of $\mathrm{CaOx}$ crystals from hexagonal to spherical shape with increasing concentrations of $\mathrm{AE}$ and reduced the dimensions such as area, perimeter, length and width of $\mathrm{CaOx}$ crystals in a dose dependent manner. Also, the Terminalia arjuna AE scavenged the DPPH (2, 2-diphenyl-1-picrylhydrazyl) radicals with an $\mathrm{IC}_{50}$ at $13.1 \mu \mathrm{g} / \mathrm{mL}$.

Conclusions: The study suggests that Terminalia arjuna bark has the potential to scavenge DPPH radicals and inhibit $\mathrm{CaOx}$ crystallization in vitro. In the light of these studies, Terminalia arjuna can be regarded as a promising candidate from natural plant sources of antilithiatic and antioxidant activity with high value.

\section{ARTICLE INFO}

\section{Key words:}

Kidney; Calculi; Calcium Oxalate; Phytotherapy; Terminalia

Int Braz J Urol. 2015; 41: 935-44

Submitted for publication:

October 29, 2014

Accepted after revision:

February 16, 2015

\section{INTRODUCTION}

Urinary stones affect a large proportion of the population. Approximately 85\% of urinary stones are calcium stones, which consist of oxalate and phosphate, either alone or in combination
(1). The mechanisms involved in the formation of urinary stones are not fully understood but it is generally agreed that urinary lithiasis is a multifaceted process involving events leading to crystal nucleation, aggregation and growth of insoluble particles (2). Crystal growth and agglomeration 
may be due to supersaturation with respect to stone forming constituents or the presence of various inhibitory or stimulatory biomolecules or even $\mathrm{pH}$ (3). Urine is always supersaturated with common stone forming minerals, however, the crystallization inhibiting capacity of urine does not allow urolithiasis to happen in most of the individuals, whereas this natural inhibition is impaired in stone formers (4).

$\mathrm{CaOx}$ stones are mostly found in two different varieties, $\mathrm{CaOx}$ monohydrate (COM) or Whewellite, and $\mathrm{CaOx}$ dihydrate (COD) or Weddellite. COM, the thermodynamically most stable form, is observed more frequently in clinical stones than COD and has a greater affinity for renal tubular cells, thus responsible for the formation of stones in the kidney (5). CaOx monohydrate (COM) has been found to initiate mineralization followed by the deposition of $\mathrm{CaOx}$ dehydrate (COD) on it (6).

Development of modern techniques such as extracorporeal shock wave lithotripsy (ESWL), percutaneous nephrolithotomy (PCNL), or ureteroscopy (URS) have revolutionized surgical management of kidney stones in recent years but do not give satisfactory results as these techniques do not prevent the likelihood of new stone formation (7). Many medicinal plants have been used since ages to treat urinary stones though the rationale behind their use is not well established through systematic and pharmacological studies, except for some composite herbal drugs and plants (8).

In recent years, numerous studies describing the therapeutic properties of extracts from different parts of various medicinal plants have been developed. Indeed, the use of such extracts as complementary and alternative medicine has lately increased, and also serves as an interesting source of drug candidates for the pharmaceutical industrial research (9). Terminalia arjuna, belonging to the family Combretaceae, holds a reputed position in Ayurvedic system of medicine since ancient times (10). Experimental and clinical studies revealed the beneficial effects of this plant against all sorts of conditions of cardiac failure (11), dropsy, anti-infective (12), anti-asthmatic and for the treatment of rheumatoid arthritis and is traditionally used to prevent the formation of kidney stone.
The present study aims to exam the antilithiatic potency of the AE of Terminalia arjuna bark on crystallization of $\mathrm{CaOx}$ in vitro and antioxidant activity of the same.

\section{MATERIALS AND METHODS}

\section{Plant}

The dried bark of was purchased from Natural Remedies Pvt. Ltd., Bangalore, India. A collection of voucher specimen is available at the company.

\section{Preparation of the AE of Terminalia arjuna}

The dried fine powdered Terminalia arjuna bark was soaked in distilled water for 24 hours at $4^{\circ} \mathrm{C}$. The extract was then filtered through muslin cloth followed by centrifugation at 10,000 rpm for 20 mins at $4^{\circ} \mathrm{C}$ and the filtrate was lyophilized to obtain the dried powder referred to as $\mathrm{AE}$ of Terminalia arjuna bark. The dried AE was stored in labeled sterile bottles and kept at $-20^{\circ} \mathrm{C}$. The various concentrations of the plant sample tested for their inhibitory potency were: $10 \mu \mathrm{g} / \mathrm{mL}, 25 \mu \mathrm{g} /$ $\mathrm{mL}, 50 \mu \mathrm{g} / \mathrm{mL}, 100 \mu \mathrm{g} / \mathrm{mL}, 200 \mu \mathrm{g} / \mathrm{mL}, 500 \mu \mathrm{g} / \mathrm{mL}$ and $1000 \mu \mathrm{g} / \mathrm{mL}$ which were prepared at the time of experiment.

\section{DPPH radical scavenging Assay}

The effect of AE of Terminalia arjuna bark on DPPH radical was estimated using the method of Liyana-Pathirana and Shahidi (13). A solution of $0.135 \mathrm{mM}$ DPPH in methanol was prepared and $2.0 \mathrm{~mL}$ of this solution was mixed with $2.0 \mathrm{~mL}$ of extract in methanol. The reaction mixture was vortexed thoroughly and left in the dark at room temperature for $30 \mathrm{~min}$. The absorbance of the mixture was measured spectrophotometrically at $517 \mathrm{~nm}$. Ascorbic acid was used as reference. The $\mathrm{IC}_{50}$ value was defined as the concentration ( $\mu \mathrm{g} /$ $\mathrm{mL}$ ) of extracts that scavenges the DPPH radicals by $50 \%$. The ability to scavenge DPPH radical was calculated by the following equation: DPPH radical scavenging activity $(\%)=(($ Acontrol-Asample $) /$ Acontrol) $\times 100$ where Acontrol is the absorbance of DPPH radical plus methanol, Asample is the absorbance of DPPH radical plus sample extract/ standard. Methanol was used as a blank. 


\section{$\mathrm{CaOx}$ crystallization assay}

Stock solutions of $10.0 \mathrm{mM}$ calcium chloride $\left(\mathrm{CaCl}_{2}\right)$ and $1.0 \mathrm{mM}$ sodium oxalate $\left(\mathrm{Na}_{2} \mathrm{C}_{2} \mathrm{O}_{4}\right)$, containing $200 \mathrm{mM}$ sodium chloride $(\mathrm{NaCl})$ and $10 \mathrm{mM}$ sodium acetate, were adjusted to $\mathrm{pH}$ 5.7. All chemicals were of the highest purity grade available. Before being used in crystallization experiments, solutions were filtered through Millex-GV membranes with a pore diameter of $0.22 \mu \mathrm{m}$ and warmed up to $37^{\circ} \mathrm{C}$ in a water bath. For crystallization experiments, $1.5 \mathrm{~mL}$ of the $\mathrm{CaCl}_{2}$ solution was transferred into a $10 \mathrm{~mm}$ light path quartz cuvette and an additional $1.5 \mathrm{~mL}$ of the $\mathrm{Na}_{2} \mathrm{C}_{2} \mathrm{O}_{4}$ solution was then added to final assay concentrations of $5.0 \mathrm{mM}$ for calcium and $0.5 \mathrm{mM}$ for oxalate, respectively. In the cuvette, the final solutions were stirred continuously and maintained at $37^{\circ} \mathrm{C}(14,15)$.

Control experiment was performed with calcium/oxalate concentration ratio, i.e., $5.0 / 0.5 \mathrm{mM} / \mathrm{mM}$. After addition of the oxalate-containing solution, automated time-course measurements of optical density at $620 \mathrm{~nm}\left(\mathrm{OD}_{620}\right)$ were performed, i.e., $\mathrm{OD}_{620}$ was recorded after every 60 seconds over 40 minutes. Experiments with added sample $(100 \mu \mathrm{L})$, where rates of nucleation and aggregation were considerably lower, had to be extended to 60 minutes. All crystallization experiments were performed at least in triplicate. Percentage inhibition produced by the AE was calculated as (1-(Tsi/Tsc)) X100, where Tsc was the turbidity slope of the control and Tsi the turbidity slope in the presence of the inhibitor.

\section{$\mathrm{CaOx}$ crystal growth assay}

Inhibitory activity against $\mathrm{CaOx}$ crystal growth was measured using the seeded solution-depletion as say described previously by Nakagawa and colleagues (16). Briefly, an aqueous solution of $10 \mathrm{mM}$ Tris- $\mathrm{HCl}$ containing $90 \mathrm{mM} \mathrm{NaCl}$ was adjusted to $\mathrm{pH} 7.2$ with $4 \mathrm{~N} \mathrm{HC1}$. Stone slurry $(1.5 \mathrm{mg} / \mathrm{mL})$ was prepared in $50 \mathrm{mM}$ sodium acetate buffer $(\mathrm{pH}$ 5.7). CaOx monohy drate crystal seed (from FTIR identified clinical kidney stones) was added to a solution containing $1 \mathrm{mM} \mathrm{CaCl}$ and $1 \mathrm{mM} \mathrm{Na}_{2} \mathrm{C}_{2} \mathrm{O}_{4}$. The reaction of $\mathrm{CaCl}_{2}$ and $\mathrm{Na}_{2} \mathrm{C}_{2} \mathrm{O}_{4}$ with crystal seed led to deposition of $\mathrm{CaOx}\left(\mathrm{CaC}_{2} \mathrm{O}_{4}\right)$ on the crystal surfaces, thereby decreasing free oxalate that is detectable by spectrophotometry at $\lambda 214 \mathrm{~nm}$. When $\mathrm{AE}$ is added into this solution, depletion of free oxalate ions will decrease if the test sample inhibits $\mathrm{CaOx}$ crystal growth. Rate of reduction of free oxalate was calculated using the baseline value and the value after 60 seconds incubation for 20 minutes, with or without test sample. The relative inhibitory activity was calculated as follows: \% Relative inhibitory activity $=((C-S) / C) \times 100$, where $\mathrm{C}$ is the rate of reduction of free oxalate without any test sample and $\mathrm{S}$ is the rate of reduction of free oxalate with a test sample.

\section{Image Analysis of Crystal Morphology}

The stock solutions of $12.75 \mathrm{mM} \mathrm{CaCl}_{2}$ and $2.25 \mathrm{mM} \mathrm{Na}_{2} \mathrm{C}_{2} \mathrm{O}_{4}$ were used to observe the size and morphology of the crystals and to verify the effect of incubation with the test material on CaOx crystal formation. $50 \mu \mathrm{L}$ of $\mathrm{CaCl}_{2}$ solution was added to wells in a 96-well plate. To each of the wells, $50 \mu \mathrm{L}$ of test sample and $\mathrm{Na}_{2} \mathrm{C}_{2} \mathrm{O}_{4}$ solution were added to obtain final concentrations of $4.25 \mathrm{mM}$ calcium and $0.75 \mathrm{mM}$ oxalate $(17,18)$. Each concentration of $\mathrm{AE}$ was prepared in triplicate. The plates were then incubated at $37^{\circ} \mathrm{C}$ for 45 minutes. Crystal morphology was examined in five randomly selected fields at 100x magnification under an upright microscope (Olympus Corporation, Japan). Images were captured from different fields. The measurement parameters in terms of area, perimeter, length and width of $\mathrm{CaOx}$ crystals in the absence and presence of various concentrations of Terminalia arjuna $\mathrm{AE}$ were measured using the inbuilt software 'Image-Pro Plus 7.0' to show the efficacy of AE of Terminalia arjuna. Cystone was used as a positive control.

\section{Statistical analysis}

Data were expressed as mean values of three independent experiments (each in triplicate) and analyzed by ANOVA $(\mathrm{p}<0.05)$ to estimate the differences between values of extracts tested using the software GraphPad Prism version 6.01.

\section{RESULTS}

\section{DPPH radical scavenging Assay}

The antioxidant activity of AE of Terminalia arjuna was determined by measuring the DPPH 
radical scavenging activity. The AE of Terminalia arjuna bark displayed the DPPH radical scavenging activity. The ability to scavenge the DPPH radical increased with increasing concentrations of the extract in a dose-dependent manner as shown in Figure-1. The percentage of DPPH radical inhibition ranged from $25.82 \%$ at $5 \mu \mathrm{g} / \mathrm{mL}$ to $93.87 \%$ at $50 \mu \mathrm{g} / \mathrm{mL}$. The AE caused scavenging of DPPH radical with $\mathrm{IC}_{50}$ value of $13.11 \mu \mathrm{g} / \mathrm{mL}$. The chemical, ascorbic acid was used as a standard and similarly inhibited DPPH with $\mathrm{IC}_{50}$ value of $5.84 \mu \mathrm{g} / \mathrm{mL}$.

\section{CaOx crystallization assay}

At final concentrations of $5.0 \mathrm{mmol} / \mathrm{L}$ calcium and $0.5 \mathrm{mmoL} / \mathrm{L}$ oxalate, the $\mathrm{CaOx}$ crystallization inhibitory activity of Terminalia arjuna AE increased with increasing concentrations of the extract in a dose-dependent manner from 10 $\mathrm{\mu g} /$ $\mathrm{mL}$ to $1000 \mu \mathrm{g} / \mathrm{mL}$ as shown in Figure- 2 . The cystone drug at a dosage of $1000 \mu \mathrm{g} / \mathrm{mL}$ was used as a positive control.

For $\mathrm{CaOx}$ crystal nucleation, the percentage inhibition shown by the Terminalia arjuna

Figure 1 - Effect of aqueous extract of Terminalia arjuna on DPPH radicals inhibition. Data are mean $\pm S$.D of three independent observations.

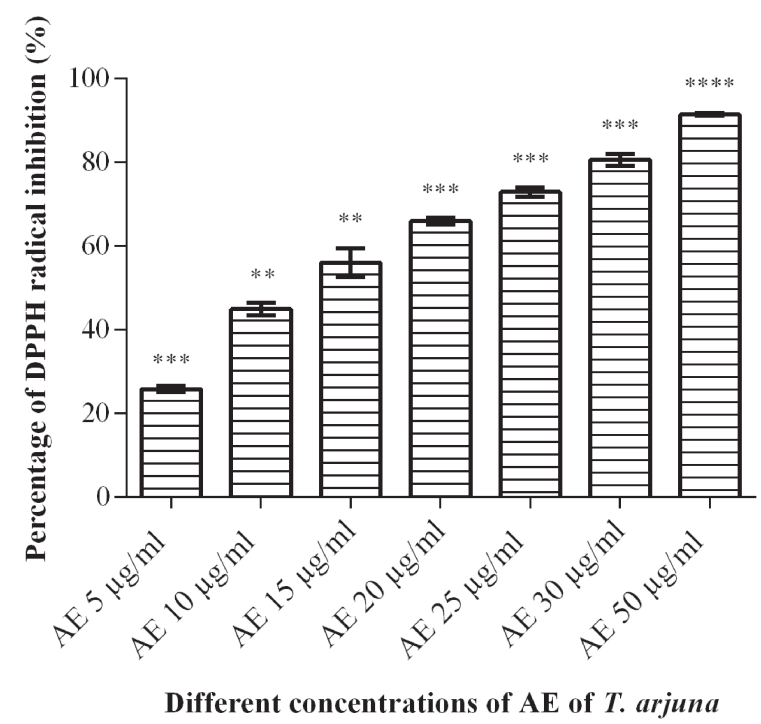

${ }^{\star \star} \mathrm{p}<0.005,{ }^{\star \star *} \mathrm{p}<0.0005,{ }^{* \star \star \star} \mathrm{p}<0.0001$ bark $\mathrm{AE}$ at $10 \mu \mathrm{g} / \mathrm{mL}, 25 \mu \mathrm{g} / \mathrm{mL}$ and $50 \mu \mathrm{g} / \mathrm{mL}$ were found to be $20.8 \pm 3.6 \%, 27.3 \pm 2.8 \%$ and $31.1 \pm 2.5 \%$ respectively. As the concentration of $\mathrm{AE}$ was increased to $100 \mu \mathrm{g} / \mathrm{mL}$, the percentage inhibition increased to $42.63 \pm 1.4 \%$. The inhibition was almost constant in the range of $45-50 \%$ at $200 \mu \mathrm{g} /$ $\mathrm{mL}$ and $500 \mu \mathrm{g} / \mathrm{mL}$ and increased upto $61.35 \pm 0.6 \%$ at $1000 \mu \mathrm{g} / \mathrm{mL}$ when compared to the control (with no plant extract). Addition of $1000 \mu \mathrm{g} / \mathrm{mL}$ cystone resulted in a nucleation percentage inhibition of $57.53 \pm 3.5 \%$.

For $\mathrm{CaOx}$ crystal aggregation, the percentage inhibition shown by the Terminalia arjuna bark $\mathrm{AE}$ at $10 \mu \mathrm{g} / \mathrm{mL}$ was found to be $31.05 \pm 5.3 \%$ which remained almost constant at $25 \mu \mathrm{g} / \mathrm{mL}$ and $50 \mu \mathrm{g} / \mathrm{mL}$. As the concentration of AE was increased to $100 \mu \mathrm{g} / \mathrm{mL}, 200 \mu \mathrm{g} / \mathrm{mL}$ and $500 \mu \mathrm{g} / \mathrm{mL}$, the percentage inhibition increased to $34.47 \pm 2.7 \%$, $39.9 \pm 2.3 \%$ and $44.6 \pm 2.4 \%$ respectively. The percentage inhibition increased to $49.8 \pm 2.4 \%$ at $1000 \mu \mathrm{g} / \mathrm{mL}$ when compared to the control (with no plant extract). Addition of $1000 \mu \mathrm{g} / \mathrm{mL}$ cystone resulted in an aggregation percentage inhibition of $69.7 \pm 4.2 \%$.

\section{$\mathrm{CaOx}$ crystal growth assay}

The AE of Terminalia arjuna bark showed the inhibitory effect on the growth of CaOx crystals as shown in Figure-3. When compared to the control (with no plant extract), the percentage inhibition at $10 \mu \mathrm{g} / \mathrm{mL}$ was found to be $13.8 \pm 1.9 \%$, which increased to $30.4 \pm 0.4 \%$ and $34.34 \pm 4.5 \%$ at $25 \mu \mathrm{g} / \mathrm{mL}$ and $50 \mu \mathrm{g} / \mathrm{mL} \mathrm{AE}$ respectively. As the concentration of $\mathrm{AE}$ was increased to $100 \mu \mathrm{g} / \mathrm{mL}$, the percentage inhibition decreased to $24.97 \pm 4.6 \%$. The percentage inhibition was significantly increased to $41.82 \pm 2.03 \%$ and $96.4 \pm 1.4 \%$ at $200 \mu \mathrm{g} / \mathrm{mL}$ and $500 \mu \mathrm{g} / \mathrm{mL}$ respectively and again reduced to $86.89 \pm 1.9 \%$ at $1000 \mu \mathrm{g} / \mathrm{mL}$. The cystone drug at a dosage of $1000 \mu \mathrm{g} / \mathrm{mL}$ was used as a positive control. Addition of $1000 \mu \mathrm{g} / \mathrm{mL}$ cystone resulted in a growth percentage inhibition of $90.67 \pm 5.9 \%$.

\section{Image Analysis of CaOx Crystal Morphology}

The incubation of metastable solutions of $4.25 \mathrm{mM}$ calcium and $0.75 \mathrm{mM}$ oxalate resulted in the formation of $\mathrm{CaOx}$ crystals composed predominately of hexagonal $\mathrm{CaOx}$ monohydrate as 
Figure 2 - Effect of aqueous extract of Terminalia arjuna on nucleation and aggregation of calcium oxalate crystals. Data are mean $\pm S$. $D$ of three independent observations.

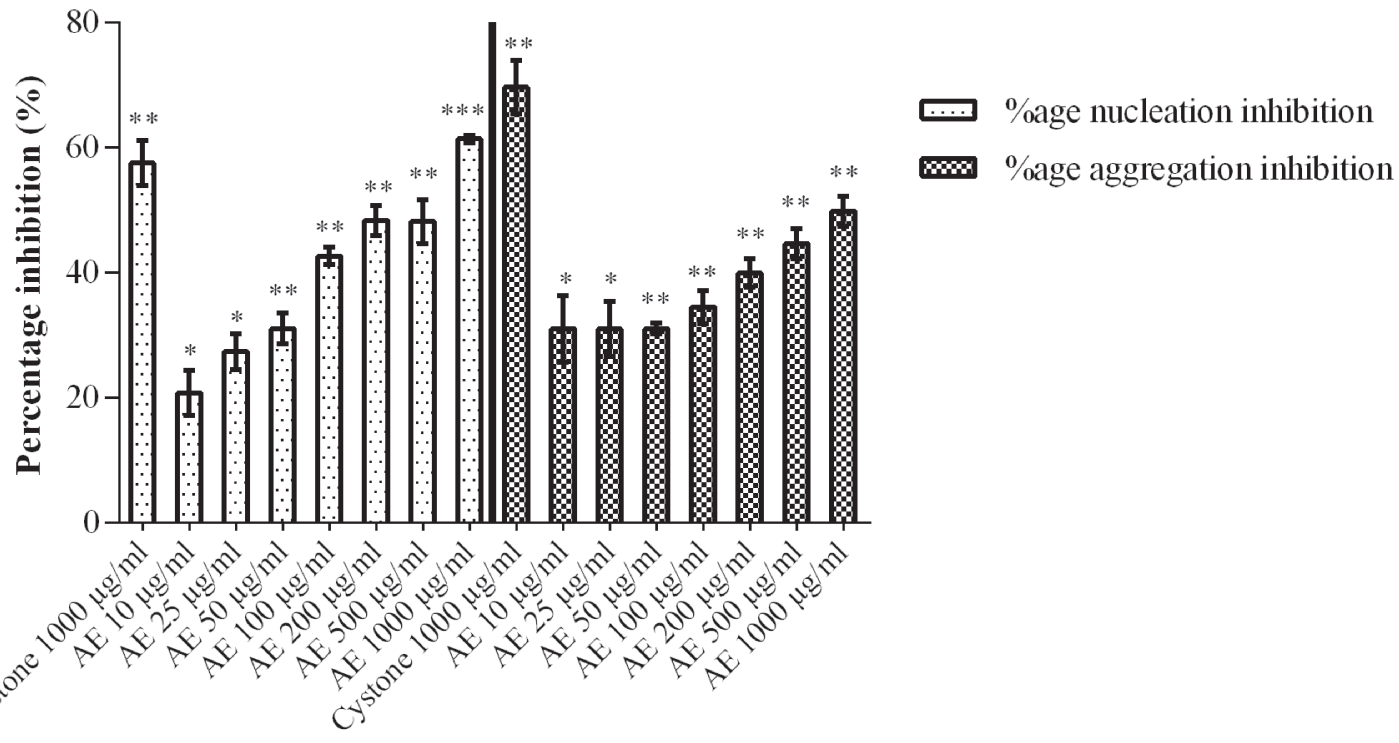

Different concentrations of AE of T. arjuna

${ }^{*} \mathrm{p}<0.05,{ }^{* *} \mathrm{p}<0.005,{ }^{* \star *} \mathrm{p}<0.0005$

Figure 3 - Effect of aqueous extract of Terminalia arjuna on growth of calcium oxalate crystals. Data are mean $\pm S$.D of three independent observations.

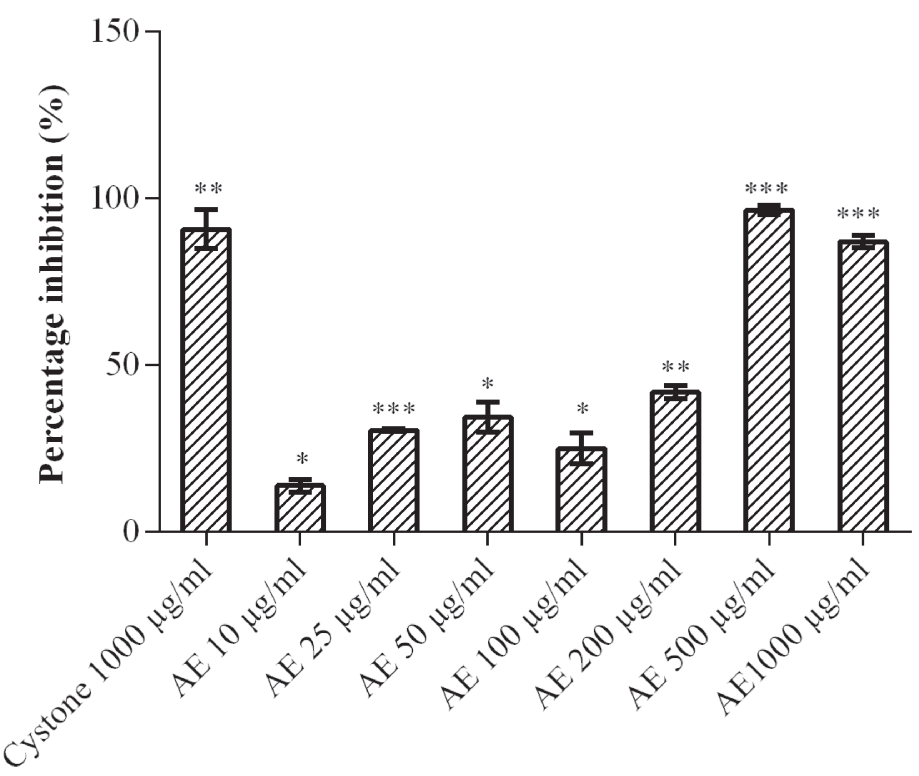

Different concentrations of AE of T. arjuna 
shown in Figure-4A. Microphotography studies showed that the AE of Terminalia arjuna bark resulted in the formation of rounded $\mathrm{CaOx}$ crystals. When compared to control (with no plant sample), the AE of Terminalia arjuna bark modified the morphology of CaOx crystals from hexagonal to spherical shape with increasing concentrations of $\mathrm{AE}$ as shown in Figure 4A-I and reduced the dimensions such as area, perimeter, length and width of $\mathrm{CaOx}$ crystals in a dose dependent manner as shown in Table-1. The CaOx crystal area, perimeter, length and width was reduced from $0.3 \mu \mathrm{m}^{2}, 2.31 \mu \mathrm{m}, 0.85 \mu \mathrm{m}$ and $0.54 \mu \mathrm{m}$ to $0.06 \mu \mathrm{m}^{2}, 0.85 \mu \mathrm{m}, 0.31 \mu \mathrm{m}$ and $0.23 \mu \mathrm{m}$ by the addition of $1000 \mu \mathrm{g} / \mathrm{mL}$ of $\mathrm{AE}$ respectively. The cystone drug at a dosage of $1000 \mu \mathrm{g} / \mathrm{mL}$ was

Figure 4 - The calcium oxalate crystals, observed under upright microscope (100x), formed in the metastable solution of calcium oxalate in the absence $(A)$ and the presence of $(B)$ cystone $(1000 \mu \mathrm{g} / \mathrm{mL})$ and Terminalia arjuna bark aqueous extract, (C-I) 10, 25, 50, 100, 200, 500 and $1000 \mu \mathrm{g} / \mathrm{mL}$.
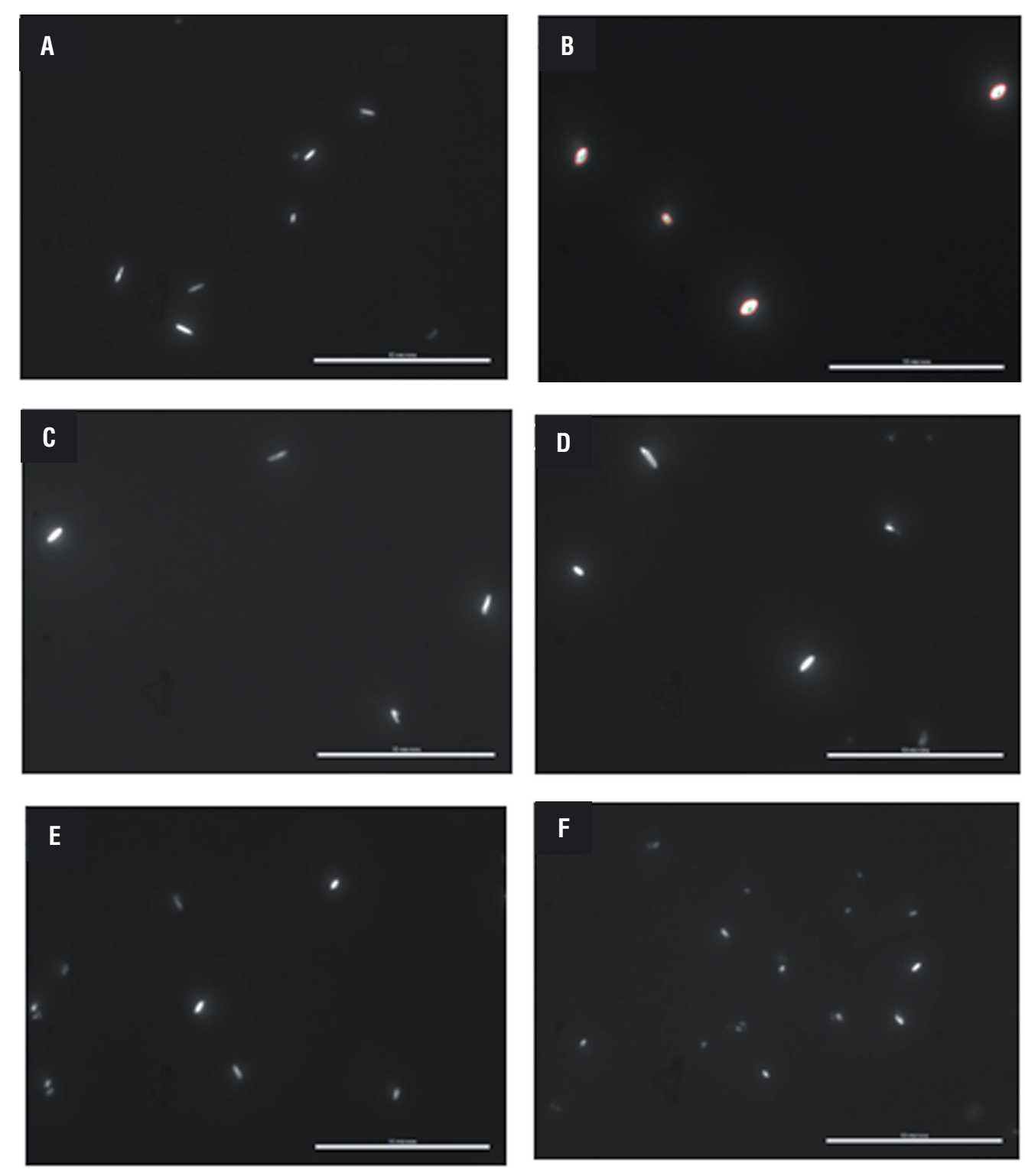

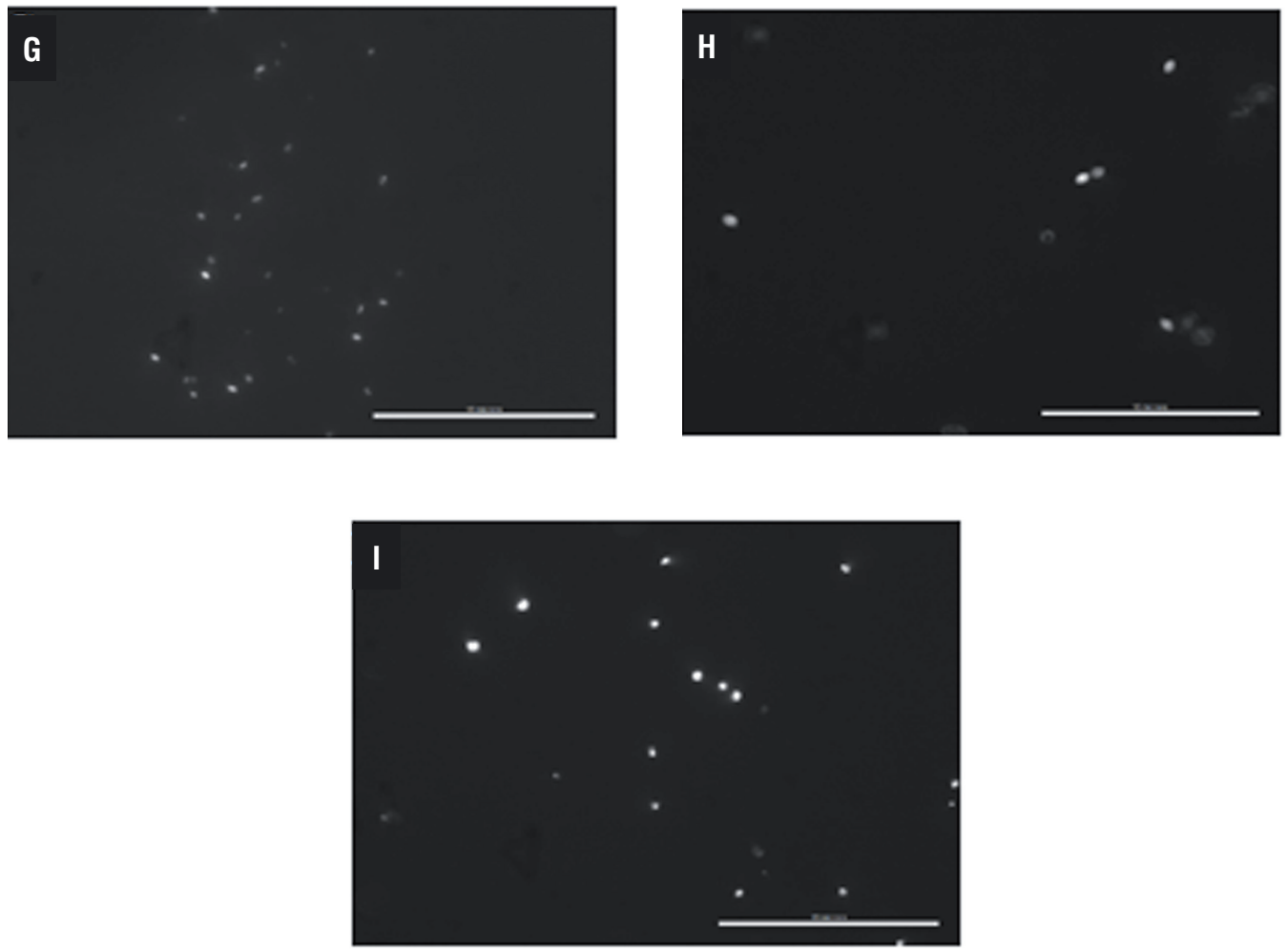

used as a positive control. Addition of $1000 \mu \mathrm{g} /$ $\mathrm{mL}$ cystone decreased the area, perimeter, length and width of $\mathrm{CaOx}$ crystals to $0.23 \mu \mathrm{m}^{2}, 1.73 \mu \mathrm{m}$, $0.64 \mu \mathrm{m}$ and $0.41 \mu \mathrm{m}$ respectively.

\section{DISCUSSION}

Hyperoxaluria is a major risk factor for $\mathrm{CaOx}$ nephrolithiasis, which in turn is associated with renal injury. High level of oxalate causes a variety of changes in the renal epithelial cells, such as an increase in free radical production and a decrease in antioxidant status, followed by cell injury and cell death. These changes are significant predisposing factors for the facilitation of crystal adherence and retention (19). Oxalate induced toxicity and free radical production are attenuated in vivo (20) and in vitro (21) by antioxidants.

A dramatic advancement in using phytotherapy for urolithiasis treatments has been observed in the recent years and many investigators have proposed scientific studies on its efficacy.
Many medicinal plants have been used since ages to treat urinary stones though the rationale behind their use is not well established. One such unexplored plant is Terminalia arjuna, commonly called as 'arjuna' or 'arjun'. The plant is said to be a divine medicine in Vedas and has a special mention in Charaka Samhita, though not much scientific study has been done to explore the antiurolithiatic potency of Terminalia arjuna, which has been established through ethnobotanical studies (10). In view of its medicinal use, Terminalia arjuna bark extract was studied to evaluate its antiurolithiatic potential using different in vitro models.

Terminalia arjuna bark AE possess very high antioxidant activity due to the presence of Terpenoids. It has the ability to scavenge the free radicals with an $\mathrm{IC}_{50}$ of $13.11 \mu \mathrm{g} / \mathrm{mL}$. Thus, pretreatment with antioxidants can block oxalate induced increases in ceramide (22). Antioxidant treatments also block oxalate-induced cell death (21), suggesting a role for oxidant stress in these responses. 
Table 1 - Effect of Terminalia arjuna aqueous extract on the morphology and dimension of calcium oxalate crystals in vitro at concentrations of $10,25,50,100,200,500$ and $1000 \mu \mathrm{g} / \mathrm{mL}$ as compared to control having Millipore water instead of aqueous extract. Data are mean $\pm S$.D of three independent observations.

\begin{tabular}{|c|c|c|c|c|c|c|c|c|c|}
\hline & Control & $\begin{array}{c}\text { Cystone } \\
1000 \mu \mathrm{g} / \\
\mathrm{mL}\end{array}$ & $\mathrm{AE} 10 \mu \mathrm{g} / \mathrm{mL}$ & $\mathrm{AE} 25 \mu \mathrm{g} / \mathrm{mL}$ & AE $50 \mu \mathrm{g} / \mathrm{mL}$ & $\mathrm{AE} 100 \mu \mathrm{g} / \mathrm{mL}$ & AE $200 \mu \mathrm{g} / \mathrm{mL}$ & AE $500 \mu \mathrm{g} / \mathrm{mL}$ & $\begin{array}{c}\text { AE 1000 } \mu \mathrm{g} / \\
\mathrm{mL}\end{array}$ \\
\hline Area $\left(\mu m^{2}\right)$ & $0.30 \pm 0.05$ & $0.23 \pm 0.14$ & $0.25 \pm 0.03$ & $0.24 \pm 0.06$ & $0.12 \pm 0.02$ & $0.09 \pm 0.03$ & $0.06 \pm 0.07$ & $0.06 \pm 0.002$ & $0.06 \pm 0.001$ \\
\hline Perimeter $(\mu \mathrm{m})$ & $2.31 \pm 0.21$ & $1.73 \pm 0.72$ & $2.04 \pm 0.26$ & $1.92 \pm 0.24$ & $1.25 \pm 0.2$ & $1.02 \pm 0.19$ & $0.84 \pm 0.07$ & $0.92 \pm 0.11$ & $0.85 \pm 0.007$ \\
\hline Length $(\mu \mathrm{m})$ & $0.85 \pm 0.0$ & $0.64 \pm 0.29$ & $0.88 \pm 0.13$ & $0.84 \pm 0.11$ & $0.51 \pm 0.07$ & $0.41 \pm 0.07$ & $0.32 \pm 0.007$ & $0.35 \pm 0.026$ & $0.31 \pm 0.01$ \\
\hline Width $(\mu \mathrm{m})$ & $0.54 \pm 0.07$ & $0.41 \pm 0.15$ & $0.35 \pm 0.02$ & $0.32 \pm 0.05$ & $0.26 \pm 0.05$ & $0.23 \pm 0.04$ & $0.20 \pm 0.006$ & $0.22 \pm 0.017$ & $0.23 \pm 0.02$ \\
\hline Shape & Hexagonal & $\begin{array}{l}\text { Hexagonal } \\
\text { with } \\
\text { rounded } \\
\text { edges }\end{array}$ & Hexagonal & $\begin{array}{l}\text { Hexagonal } \\
\text { with } \\
\text { rounded } \\
\text { edges }\end{array}$ & $\begin{array}{l}\text { Hexagonal } \\
\text { with rounded } \\
\text { edges }\end{array}$ & $\begin{array}{l}\text { Hexagonal } \\
\text { with rounded } \\
\text { edges }\end{array}$ & $\begin{array}{l}\text { Hexagonal } \\
\text { with rounded } \\
\text { edges }\end{array}$ & $\begin{array}{l}\text { Hexagonal } \\
\text { with rounded } \\
\text { edges }\end{array}$ & Spherical \\
\hline
\end{tabular}

The effect of Terminalia arjuna bark extract on $\mathrm{CaOx}$ crystallization kinetics was studied by the time course measurement of turbidity. In this study, $\mathrm{AE}$ inhibited the $\mathrm{CaC}_{2} \mathrm{O}_{4}$ crystal aggregation in a concentration-dependent manner, similar to cystone drug, a well-known drug formulated by the Himalaya to cure kidney stones and widely clinically used for the management of urolithiasis.

In the microscopic study, AE modified CaOx monohydrate crystal morphology. A similar change in the morphology of $\mathrm{CaOx}$ monohydrate crystals has been previously reported with citrate and $\mathrm{Mg}^{2+}$ (23). Microphotography studies verified that AE of Terminalia arjuna resulted in the formation of round $\mathrm{CaOx}$ crystals. $\mathrm{COM}$ and $\mathrm{COD}$ are the major forms found in most urinary calculi. AE of Terminalia arjuna inhibited the growth of COM crystals, prevented the aggregation of COM crystals, and induced the formation of spherical COM crystals. These spherical COM crystals are thermodynamically less stable phase and have weaker affınity for cell membranes than hexagonal COM crystals. Both Terminalia arjuna AE $(1 \mathrm{mg} / \mathrm{mL})$ and cystone $(1 \mathrm{mg} / \mathrm{mL})$ resulted in the shape changes of $\mathrm{CaOx}$ crystals, as shown in Figures 4B and 4I; a more rounded polygonal crystals shape. This shape may prevent the formation of kidney stones, because crystals with this shape are more easily excreted in the urine compared with the COM.

Formation of crystals along urinary tract, driven by urinary supersaturation, is a primary requisition for the subsequent stone formation (24), although crystal formation does not necessarily lead to stone formation. Researchers have identified crystal retention as a critical step for the formation of clinically symptomatic stone from a free particle. Various physiological inhibitors of urolithiasis found in urine including citrate have been shown to decrease the saturation of $\mathrm{CaC}_{2} \mathrm{O}_{4}$ and inhibit crystal nucleation, growth and aggregation, while reduced crystallization inhibiting capacity of urine can play a role in stone formation (3). Interference with crystal growth and aggregation therefore seems a possible therapeutic strategy for the prevention of recurrent stone disease.

Terminalia arjuna bark extract is previously reported to inhibit $\mathrm{CaOx}$ crystal precipitation and growth (25). These results were verified in previous studies and also showed the change in the shape $\mathrm{CaOx}$ crystals in the presence of Terminalia arjuna bark AE. Recently, several plants including Herniaria hirsuta (26), Tribulus terrestris (5), Terminalia chebula (27) and Bergenia ligulata (17), are being explored for their antiurolithiatic 
property on the basis of their usage in the traditional medicine. An extract of $\mathrm{H}$. hirsuta increased the $\mathrm{CaOx}$ crystal number but decreased their size. It also promoted the formation of $\mathrm{CaOx}$ dihydrate crystals, despite the presence of $\mathrm{CaOx}$ monohydrate particles (26). B. ligulata is a widely used plant in South Asia, mainly India and Pakistan, as a traditional medicine for the treatment of urolithiasis. The crude aqueous-methanolic extract of B. ligulata rhizome (BLR) was studied using in vitro and in vivo methods and the extract showed the antiurolithic activity through $\mathrm{CaOx}$ crystal inhibition, diuretic, hypermagneseuric and antioxidant effects (17). Very recently, in our lab, antilithiatic potency of Dolichos biflorus (28) and Trachyspermum ammi (29) has been evaluated in vitro and in vivo. Antilithiatic proteins were identified and characterized from these plants adding a new vista to study therapeutic proteins from plants.

\section{CONCLUSION}

This study demonstrated that AE of Terminalia arjuna possess a high antioxidant activity and an ability to inhibit the $\mathrm{CaOx}$ crystallization in vitro. In addition, this extract changed the morphology and reduced the dimensions of hexagonal COM crystals to spherical COM crystals. This shape may prevent the formation of kidney stones. In the light of these studies, Terminalia arjuna can be regarded as a promising candidate from natural plant sources of antilithiatic and antioxidant activity with high value.

\section{ABBREVIATIONS}

$\mathrm{CaOx}=$ Calcium oxalate

$\mathrm{AE}=$ Aqueous extract

$\mathrm{T}$. arjuna $=$ Terminalia arjuna

$\mathrm{COM}=$ Calcium oxalate monohydrate

COD = Calcium oxalate dihydrate

ESWL $=$ Extra corporeal shock wave lithotripsy

PCNL $=$ Percutaneous nephrolithotomy

URS = Ureteroscopy

DPPH = 2, 2-diphenyl-1-picrylhydrazyl

\section{CONFLICT OF INTEREST}

None declared.

\section{REFERENCES}

1. Basavaraj DR, Biyani CS, Browning AJ, Cartledge JJ. The role of urinary kidney stone inhibitors and promoters in the pathogenesis of calcium containing renal stones. EAU-EBU Update Ser. 2007; 5:126-36.

2. Baumann JM. Stone prevention: why so little progress? Urol Res. 1998; 26:77-81.

3. Fan J, Schwille PO, Schmiedl A, Gottlieb D, Manoharan M, Herrmann U: Calcium oxalate crystallization in undiluted urine of healthy males: in vitro and in vivo effects of various citrate compounds. Scanning Microsc. 1999; 13:307-19.

4. Tiselius HG, Hallin A, Lindbäck B. Crystallisation properties in stone forming and normal subjects' urine diluted using a standardised procedure to match the composition of urine in the distal part of the distal tubule and the middle part of the collecting duct. Urol Res. 2001; 29:75-82.

5. Aggarwal A, Tandon S, Singla SK, Tandon C. Diminution of oxalate induced renal tubular epithelial cell injury and inhibition of calcium oxalate crystallization in vitro by aqueous extract of Tribulus terrestris. Int Braz J Urol. 2010; 36:480-8; discussion 488, 489

6. Verkoelen CF, Romijn JC, de Bruijn WC, Boevé ER, Cao LC, Schröder $\mathrm{FH}$. Association of calcium oxalate monohydrate crystals with MDCK cells. Kidney Int. 1995; 48:129-38.

7. Pak CY. Prevention and treatment of kidney stones. Role of medical prevention. J Urol. 1989; 141:798-801.

8. Jethi RK, Duggal B, Sahota RS, Gupta M, Sofat IB. Effect of the aqueous extract of an Ayurvedic compound preparation on mineralization \& demineralization reactions. Indian J Med Res. 1983; 78:422-5.

9. Newman DJ, Cragg GM. Natural products as sources of new drugs over the last 25 years. J Nat Prod. 2007; 70:461-77.

10. Scassellati-Sforzolini G, Villarini LM, Moretti LM, Marcarelli LM, Pasquini R, Fatigoni C, et al. Antigenotoxic properties of Terminalia arjuna bark extracts. J Environ Pathol Toxicol Oncol. 1999; 18:119-25.

11. Cheng HY, Lin CC, Lin TC. Antiherpes simplex virus type 2 activity of casuarinin from the bark of Terminalia arjuna Linn. Antiviral Res. 2002; 55:447-55.

12. Nagpal A, Meena LS, Kaur S, Grover IS, Wadhwa R, Kaul SC. Growth suppression of human transformed cells by treatment with bark extracts from a medicinal plant, Terminalia arjuna. In Vitro Cell Dev Biol Anim. 2000; 36:544-7. 
13. Liyana-Pathirana CM, Shahidi F. Antioxidant activity of commercial soft and hard wheat (Triticum aestivum L.) as affected by gastric pH conditions. J Agric Food Chem. 2005; 53:2433-40.

14. Hess B, Meinhardt U, Zipperle L, Giovanoli R, Jaeger P. Simultaneous measurements of calcium oxalate crystal nucleation and aggregation: impact of various modifiers. Urol Res. 1995; 23:231-8.

15. Hess B, Jordi S, Zipperle L, Ettinger E, Giovanoli R. Citrate determines calcium oxalate crystallization kinetics and crystal morphology-studies in the presence of Tamm-Horsfall protein of a healthy subject and a severely recurrent calcium stone former. Nephrol Dial Transplant. 2000; 15:366-74.

16. Chutipongtanate $S$, Nakagawa $\mathrm{Y}$, Sritippayawan $\mathrm{S}$, Pittayamateekul J, Parichatikanond P, Westley BR, et al. Identification of human urinary trefoil factor 1 as a novel calcium oxalate crystal growth inhibitor. J Clin Invest. 2005; 115:3613-22.

17. Bashir S, Gilani AH. Antiurolithic effect of Bergenia ligulata rhizome: na explanation of the underlying mechanisms. J Ethnopharmacol. 2009; 122:106-16.

18. Zhang CY, Wu WH, Wang J, Lan MB. Antioxidant properties of polysaccharide from the brown seaweed Sargassum graminifolium (Turn.), and its effects on calcium oxalate crystallization. Mar Drugs. 2012; 10:119-30.

19. Khan SR. Calcium oxalate crystal interaction with renal tubular epithelium, mechanism of crystal adhesion and its impact on stone development. Urol Res. 1995; 23:71-9.

20. Selvam R. Calcium oxalate stone disease: role of lipid peroxidation and antioxidants. Urol Res. 2002; 30:35-47.

21. Thamilselvan S, Byer KJ, Hackett RL, Khan SR. Free radical scavengers, catalase and superoxide dismutase provide protection from oxalate-associated injury to LLC-PK1 and MDCK cells. J Urol. 2000; 164:224-9.

22. Cao LC, Honeyman T, Jonassen J, Scheid C. Oxalate-induced ceramide accumulation in Madin-Darby canine kidney and LLC-PK1 cells. Kidney Int. 2000; 57:2403-11.
23. Guerra A, Meschi T, Allegri F, Prati B, Nouvenne A, Fiaccadori $E$, et al. Concentrated urine and diluted urine: the effects of citrate and magnesium on the crystallization of calcium oxalate induced in vitro by an oxalate load. Urol Res.2006; 34:359-64.

24. Finlayson B, Khan SR, Hackett RL. Mechanisms of stone formation--an overview. Scan Electron Microsc. 1984; (Pt 3):1419-25.

25. Chaudhary A, Singla SK, Tandon C. In vitro Evaluation of Terminalia arjuna on Calcium Phosphate and Calcium Oxalate Crystallization. Indian J Pharm Sci. 2010; 72:340-5.

26. Atmani F, Khan SR. Effects of an extract from Herniaria hirsuta on calcium oxalate crystallization in vitro. BJU Int. 2000; 85:621-5.

27. Tayal S, Duggal S, Bandyopadhyay P, Aggarwal A, Tandon $\mathrm{S}$, Tandon C. Cytoprotective role of the aqueous extract of Terminalia chebula on renal epithelial cells. Int Braz J Urol. 2012; 38:204-13.

28. Bijarnia RK, Kaur T, Singla SK, Tandon C. A novel calcium oxalate crystal growth inhibitory protein from the seeds of Dolichos biflorus (L.). Protein J. 2009; 28:161-8.

29. Kaur T, Bijarnia RK, Singla SK, Tandon C. Purification and characterization of an anticalcifying protein from the seeds of Trachyspermum ammi (L.). Protein Pept Lett. 2009; 16:173-81.

\author{
Correspondence address: \\ C. Tandon, $\mathrm{PhD}$ \\ Director, \\ Amity Institute of Biotechnology \\ Amity University Uttar Pradesh, \\ Sector - 125, Noida - 201313 (U.P.), India \\ Fax: +91 120 439-2947 \\ E-mail: ctandon@amity.edu
}

